\title{
The Effect of Different Cover and Flooring Materials on Climatic Comfort in Landscape Design ${ }^{\#}$
}

\author{
Orhun Soydan ${ }^{1, a}$, Ahmet Benliay ${ }^{2, b, *}$ \\ ${ }^{1}$ Landscape Architecture Department, Faculty of Architecture, Niğde Ömer Halisdemir University, 51240 Niğde, Turkey \\ ${ }^{2}$ Landscape Architecture Department, Faculty of Architecture, Akdeniz University, 07070 Antalya, Turkey
}

*Corresponding author

\begin{tabular}{|c|c|}
\hline R T I C L E I N F O & $\mathrm{R} \mathrm{A} \mathrm{C} \mathrm{T}$ \\
\hline $\begin{array}{l}\text { "This study was presented as an online } \\
\text { presentation at the } 2^{\text {nd }} \text { International } \\
\text { Journal of Agriculture - Food Science } \\
\text { and Technology (TURJAF 2021) } \\
\text { Gazimağusa/Cyprus }\end{array}$ & $\begin{array}{l}\text { In this study, it is aimed to understand the effects of structural and vegetative elements that can be } \\
\text { used in landscape designs on the temperature factor, which will greatly affect the climatic comfort, } \\
\text { by using artificial neural networks. In this context, measurements were carried out in the morning } \\
(08: 00-09: 00) \text {, noon }(13: 00-14: 00) \text { and evening }(17: 00-18: 00) \text { of a total of } 100 \text { days, } 50 \text { days in each } \\
\text { of the winter and summer seasons, at } 7 \text { randomly selected points in the Akdeniz University Campus. } \\
\text { In these measurements, the temperature difference values of } 11 \text { cover elements on } 7 \text { different floor } \\
\text { covering types were measured, and the ambient air temperature, humidity and wind values were } \\
\text { also determined. The temperature differences between the areas where the flooring elements are } \\
\text { exposed to direct sun and the shadow effect of different plant and cover elements were determined } \\
\text { using an infrared laser thermometer. These values were processed with Neural Designer software } \\
\text { and possible temperature difference prediction values were created for } 57.750 \text { different alternatives } \\
\text { with the help of artificial neural network model from } 837 \text { sets of data. Evaluation shows that the } \\
\text { maximum temperature difference is } 15.6^{\circ} \mathrm{C} \text { at noon in the summer months in the red tartan flooring } \\
\text { material and Callistemon viminalis cover material. While the artificial neural network model } \\
\text { predicts that there will be a high } 2-3^{\circ} \mathrm{C} \text { temperature difference for the alternatives, it has made } \\
\text { predictions for temperature differences between } 0-10^{\circ} \mathrm{C} \text { in winter and } 0 \text { - } 16^{\circ} \mathrm{C} \text { in summer months. } \\
\text { Although the temperature differences that will occur in the noon hours are distributed over a wide } \\
\text { range of values, it seems that the morning and evening forecasts are concentrated between } 0-7^{\circ} \mathrm{C} \\
\text { values. Also, it has been determined that the wind and humidity in the environment are more } \\
\text { important factors than the ambient temperature in terms of temperature differences. }\end{array}$ \\
\hline
\end{tabular}

a@orhunsoydan@ohu.edu.tr (i) https://orcid.org/0000-0003-0723-921X |b benliay@akdeniz.edu.tr $\quad$ (D) https://orcid.org/0000-0002-0902-2658

(c) 9 () (9) This work is licensed under Creative Commons Attribution 4.0 International License

\section{Introduction}

The Climate is an important factor of landscape because of the effect on the formation and determination of other landscape elements. In many landscapes, the climate is constantly and largely effective, down to the finest classification (Güngör, 2003).

Humans expend a certain amount of energy to reach a state of bioclimatic comfort or to adapt to their environment. Bioclimatic comfort status is defined as the conditions in which a person can adapt to his environment by spending the least amount of energy (Çetin et al., 2010).

Researchers have demonstrated the effects of climate on human comfort by examining different climate components in their studies. They give identical results in many respects among themselves. These studies generally focus on air temperature, wind, humidity, and solar radiation as in the studies of Carpenter et al. (1975) and Robinette et al. (1983). However, according to Marsh (1991), there are 5 climatic factors that affect climate comfort. These; air temperature, humidity, solar radiation, wind, and air pollutants.
Comfort zone is an area where the ambient temperature is between $15^{\circ} \mathrm{C}$ and $20^{\circ} \mathrm{C}$ and the humidity level is between $20 \%$ and $80 \%$, limited by the influence of other components. But sometimes the built environment produces changes in this comfort zone, such as the configuration, orientation, and arrangement of the hardscape in a region. However, different parameters create different microclimate values for each region and person (Figure 1).

These factors can be changed with a proposed landscape design and climatic comfort values can be changed. Although much larger measures for air pollutants need to be developed, the ambient humidity can be increased with a pool, fountain, or pond to be built in the space, or the wind speed and direction can be changed with the planting design. However, solar radiation value and ambient temperature can be changed most effectively with the use of landscape designs. 


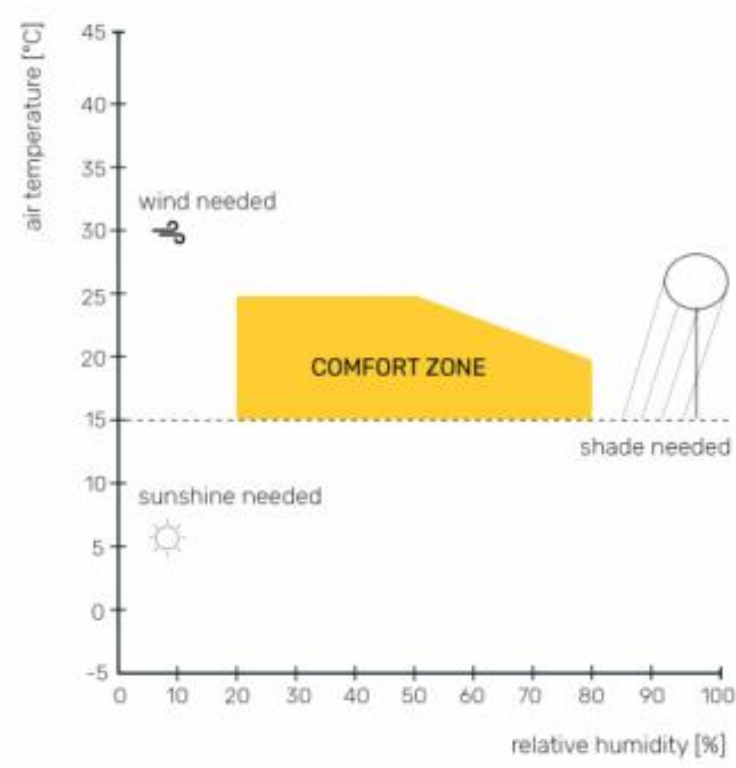

Figure 1. Comfort zone

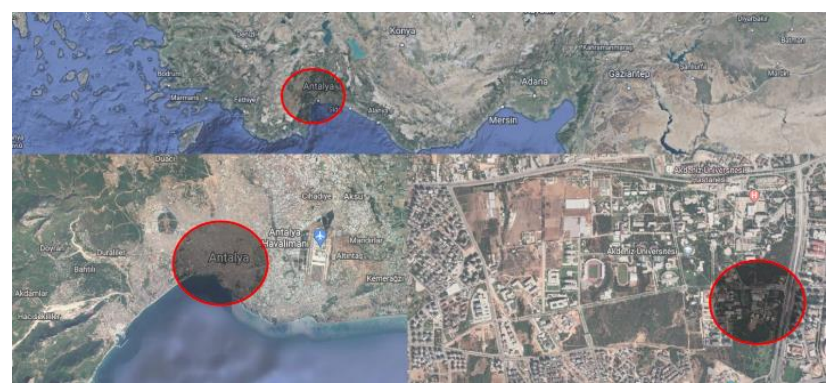

Figure 2. Study area

To make such a change, the concepts of ambient temperature and solar radiation belonging to a region should be well studied. The location of a region on the earth is to determine the temperature values depending on its distance from the sun during the year and the angle of receiving the sun's rays, but it is seen that the temperature environments of different places at the same latitude are not the same. The reason for this is the intensity of solar radiation varying from region to region, the effect of atmospheric conditions on the sun's rays, the earthatmosphere relationship, the amount of energy resulting from the physical change of matter, and the direction and intensity of air movements (Özdemir, 2015). In general, temperature is the average kinetic energy temperature of an object. The amount of heat received by the earth is called temperature (Yücer, 2015). The change in the amount of sunlight falling on the earth's surface causes the ambient temperature to change. Therefore, sun position, light and shade have a great importance on solar radiation and climatic comfort is affected by the presence of shade. Although the use of shading elements such as pergola provides this but, it is known that some plants used in designs can change these values to a large extent. Many studies have proven that urban greenery, especially trees, can positively affect the outdoor microclimate and alleviate the urban heat island effect in summer (Wang et al., 2015). This study aimed to improve the understanding of the effects of different plant species on solar radiation which is an important factor in climatic comfort.
In this study, artificial neural networks were used for data analysis and evaluation. Artificial neural networks (ANNs) are computer software in which basic functions such as generating new data from the data collected by the brain by learning, remembering, and generalizing by imitating the learning path of the human brain are performed. Artificial neural networks, inspired by the human brain, emerged as a result of the mathematical modeling of the learning process (Kabalc1, 2014). Artificial Neural Networks applications are mostly used in prediction, classification, data association, data interpretation and data filtering (Öztürk and Şahin, 2018).

\section{Materials and Method}

In the study, the Artificial Neural Networks model, which uses the Neural Designer infrastructure to find out the effects of different top covers and floor materials on climate comfort, was carried out at 7 randomly selected points within the Akdeniz University Campus which is in Antalya, Turkey. Measurements were carried out around Akdeniz University Social Facilities Buildings and DSI Water Collection area (Figure 2).

Measurements were carried out at for a total of 100 days, 50 days in each of the winter and summer seasons, in the morning (08:00-09:00), noon (12:00-13:00) and evening hours (17:00-18:00). Air temperature, humidity and wind measurements were made in 7 different areas where the determined plants and cover elements are located. In the study, measurements were made with laser thermometer (for measuring shade and sunny areas), humidity meter (hydrometer) and digital thermometer (for measuring ambient temperature). The temperature of the sun and shaded areas was measured and combined with numerical modelling. 7 sub-criteria were determined in the evaluation. These are;

- Season (D1-2): Winter are Summer,

- Measurement Time (D2-3): Morning, Afternoon and Evening,

- Flooring Material (D3-7): Travertine, Interlocking parquet, Tartan (Red), Soil, Grass, Concrete and Acrylic,

- Top Cover (D4-11): Pergola, Pinus pinea, Bauhinia variegata, Taxodium distichum, Callistemon viminalis, Parkinsonia aculeata, Ficus Benjamin, Celtis australis, Eucalyptus camaldulensis, Platanus orientalisa and Erythrina lysistemon,

- Ambient Temperature (D5-5): 10-15, 16-20, 21-25, 26-30 and $31+$,

- $\quad$ Wind speed (D6-5): 0.0-0.5, 0.6-1.0, 1.1-1.5, 1.6-2.0, $2.1+$,

- Ambient humidity (D7-5): 0-40, 41-45, 46-50, 51-55, $56+$.

These criteria were processed with Neural Designer software and possible temperature difference prediction values were created for 57750 different alternatives with the help of artificial neural network model trained from 837 sets of data. Parameters, models, and features used in the preparation of the artificial neural network model are given in Table 1. 
Table 1. Artificial neural network model description

\begin{tabular}{|c|c|c|}
\hline Name & Description & Value \\
\hline Inverse Hessian approximation method & Method used to obtain a suitable training rate. & BFGS \\
\hline Training rate method & $\begin{array}{l}\text { Method used to calculate the step for the quasi- } \\
\text { Newton training direction }\end{array}$ & BrentMethod \\
\hline Training rate tolerance & Maximum interval length for the training rate & 0.01 \\
\hline Minimum parameters increment norm & $\begin{array}{l}\text { Norm of the parameters increment vector at } \\
\text { which training stops }\end{array}$ & $1 \mathrm{e}-006$ \\
\hline Minimum loss increase & $\begin{array}{l}\text { Minimum loss improvement between two } \\
\text { successive iterations }\end{array}$ & $1 e-009$ \\
\hline Performance goal & Goal value for the loss & $1 \mathrm{e}-006$ \\
\hline Gradient norm goal & $\begin{array}{l}\text { Goal value for the norm of the objective function } \\
\text { gradient }\end{array}$ & 0.01 \\
\hline Maximum selection loss increases & $\begin{array}{l}\text { Maximum number of iterations at which the } \\
\text { selection loss increases }\end{array}$ & 100 \\
\hline Maximum iterations number & $\begin{array}{l}\text { Maximum number of iterations to perform the } \\
\text { training }\end{array}$ & 10000 \\
\hline Maximum time & Maximum training time & 3600 \\
\hline Reserve parameters norm history & $\begin{array}{l}\text { Plot a graph with the parameters norm of each } \\
\text { iteration }\end{array}$ & false \\
\hline Reserve loss history & Plot a graph with the loss of each iteration & true \\
\hline Reserve selection loss history & $\begin{array}{l}\text { Plot a graph with the selection loss of each } \\
\text { iteration }\end{array}$ & false \\
\hline Reserve gradient norm history & $\begin{array}{l}\text { Plot a graph with the gradient norm of each } \\
\text { iteration }\end{array}$ & false \\
\hline
\end{tabular}

A coding system was developed to find values that may change based on sub-criteria and temperature change values were determined for code values. Each sub-category has been sorted to correspond to different numbers and added sequentially according to the order in which they are. Since there are more than 10 in this section, the top cover sub-criteria value was evaluated as two digits, and the number " 0 " was added to the coding system before the numbers less than 10 .

For instance, the code generated for a forecast with Season: Winter (1), Measurement Time: Noon (2), Flooring Material Grass (5), Top Cover: Ficus Benjamin (07), Ambient Temperature: 10-15 (1), Wind speed: 0.00.5 (1) and Ambient humidity: 0-40 (1) is determined as: 12507111. Likewise, the code generated for a forecast with Season: Summer (2), Measurement Time: Morning (1), Flooring Material: Travertine (1), Top Cover: Platanus orientalis (10), Ambient Temperature: 21-25 (3), Wind speed: $0.5-1.0$ (2) and Ambient humidity: 41-45 (2) is determined as: 21110322. With the help of the trained model, the Neural designer software was asked to generate predictions for the code values formed from each subcategory. Prediction values are listed and added to the database so that they can be used in querying. The code values that emerged as the highest difference in the classified values were determined and the potential reasons for this were discussed. As a result of the study, the advantages, and disadvantages of the method used and the problems which are encountered, are mentioned.

\section{Results and Discussion}

The measurements made for 100 days were prepared to train the artificial neural network model and evaluated with the Neural Designer software. During the artificial neural network model training, the final loss value of 0.492 was reached with 252 iteration number and the minimum parameters increment norm was reached. The required training was stopped because it was found sufficient by the neural designer and a model suitable for data estimation emerged (Figure 3).

Training inputs and their correlation on corresponding output values are given in Table 2 . The input values are sub-category values as D1, D2, D3, D4, D5, D6, and D7, and the output value is forecast values.

This result shows that Season (D1) and Ambient humidity (D7) has a higher effect on forecast values. Seasons are closely related to the amount of ambient temperature and the foliation of plants. This may be particularly significant for measurements related to solar radiation. However, the emergence of ambient humidity as a high-rate modifier is one of the interesting results of the study.

Although there was not much difference between the other criteria, the Top Cover and Flooring Materia criteria were found as least effective amongst others. This situation can be interpreted as the number of variables in the criteria is high and these variables are not as effective as other parameters on the measurement values due to their structure. Output values are differing from $0.1^{\circ} \mathrm{C}$ to $15.109^{\circ} \mathrm{C}$ as the model predicted. The predictions have a mean of 3.3884 and a standard deviation of 1.9386 (Table 3).

Finding the average of the temperature prediction values as $3.38^{\circ} \mathrm{C}$ is one of the important outputs of the study. To determine at which temperature degrees the sub-criteria are most effective, classification was made within the scope of code values. It has been determined that the highest value can be achieved with Callistemon viminalis top cover material, at $2.1+\mathrm{km} / \mathrm{h}$ and higher speeds, in the range of $0 \%-40 \%$ humidity, at an ambient temperature of 16-20 degrees, on red tartan flooring, at noon, in summer. Callistemon viminalis is mostly above the general average values, although not much compared to other cover elements, the fact that the estimated 
values are as high as $15.109^{\circ} \mathrm{C}$ is a proof of how effective the diversity in the other variables can be on the surface temperature differences.

In order to see the cluster groups outside the mean of temperature change value estimates, distribution and ratio tables were created according to the criteria. These are given as sub-categories and temperature change forecast values - rates total difference is given in Table 4 and subcategories and temperature change forecast values - rates for subcategories is given in Table 5 .

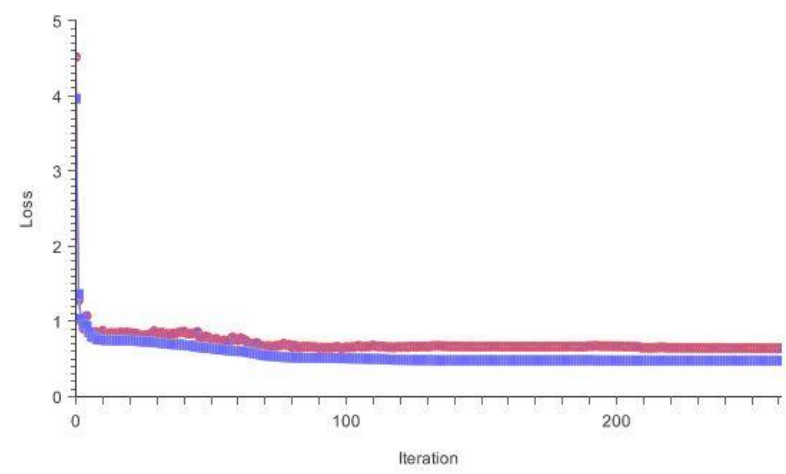

Figure 3. Artificial neural network loss and iteration chart

Table 2. Input and Output value correlations

\begin{tabular}{l|c}
\hline \multicolumn{1}{c|}{ Classification } & Value \\
\hline D1 & 1.5247 \\
D2 & 2.00716 \\
D3 & 3.74344 \\
D4 & 5.90811 \\
D5 & 2.027446 \\
D6 & 1.82339 \\
D7 & 1.54241 \\
Forecast & 3.83699 \\
\hline
\end{tabular}

Table 3. Prediction descriptive statistics

\begin{tabular}{l|c}
\hline \multicolumn{1}{c|}{ Value } & Forecast \\
\hline Minimum & 0.1 \\
Maximum & 15.109 \\
Mean & 3.3884 \\
Deviation & 1.9386 \\
\hline
\end{tabular}

These charts show that beside the mean value main distribution is in $2-3^{\circ} \mathrm{C}(54.21 \%)$ and most effective Top covers are Bauhinia variegata, Taxodium distichum, Callistemon viminalis, and Parkinsonia aculeata among others. Also, higher temperature differences mainly shown in Concrete, and Acrylic flooring materials. As it can be predicted, the temperature change forecast values in the summer months show distribution, although it intensifies between $2-3^{\circ} \mathrm{C}$ in the winter months $(60.70 \%)$. Also, the predictions are mainly in $2-3^{\circ} \mathrm{C}(79.35 \%)$ in forecast for morning timeline. Forecast values for wind speed, which has the most correlations, scatter as the wind speed slows down, and are getting closer in the $2-3^{\circ} \mathrm{C}$ values as the wind speed increases.

\section{Conclusions}

The landscape designer who must focus on peopleoriented space designers, has to make important decisions regarding the material to be used and how the plant design should be. Designs should respond not only to aesthetic but also to functional needs of people. As always, the most important factor affecting their design selection is the climate and climatic comfort zone.

Although the climatic comfort zone varies from person to person, the activity and the clothes used, people ask a cool place protected from the sun in summer and a warm place in contact with the sun in winter. The factor that changes the climatic comfort the most is the surface temperature. The change in this value may cause the required temperature value to decrease in winter and to increase in summer. With the study, temperature change values of 13 different top cover and 7 different flooring elements belonging to the province of Antalya for summer and winter months, which are of great importance in terms of climatic comfort, were found.

A numerical estimation value was created for each subcategory value changed in the factors together with the created algorithm and code values for Antalya city. The possibility of realizing a web-based, mobile or desktop software with the help of the obtained values increases the importance of the study. It should be noted that this study can only produce results based on Antalya Climate structure. The data obtained cannot be used for another city or region. Within this method, it is necessary to make measurements in other regions and to prepare their algorithms. The method used focused on 1 pergola which is an artificial material, and 10 trees. It is possible to include artificial cover elements and many other tree species in this method and to create more suitable and detailed data for landscape design studies.

One of the advantages of the working method is that sharper results can be obtained with a small amount of data with the artificial neural network method, which is also called data mining. Another important issue for the study is the variables. It is necessary to include inputs such as Plant Crown, Plant Age, Plant Height in the scope of the study. However, the input data to be used in this study will increase, which will lead to a large increase in the number of 57.750 determined codes in the example.

The measurement accuracy is an other important subject to consider. Even if the devices used in the study are calibrated, instantaneous calculation differences may occur. With a single detector, it is not possible to take two measurements at the same time. One of the methods that will allow measurement at the same time can be the use of thermal cameras. With the help of a camera that offers high resolution capturing, the data of a region that is both in the shade and exposed to the sun can be collected at the same time. However, the high prices of thermal cameras, which provide quality images, may reduce their preference in this type of work today. It is possible that the prices of such imaging and analysis devices will decrease with the developments in technology.

Changes in environmental conditions can cause measurement times to change. Factors such as local microclimate areas, air pollution in the environment, etc. can reduce the efficiency of the work. The factor that causes the most delays during the work is the low number of direct sunny days in the winter months. For the study, only 50 days of measurement can be made in total due to rain or cloudy weather in winter. 
Table 4. Sub-categories and temperature change forecast values - rates total difference

\begin{tabular}{|c|c|c|c|c|c|c|c|c|c|c|c|c|c|}
\hline & \multicolumn{2}{|l|}{ D1 } & \multicolumn{3}{|l|}{ D2 } & \multicolumn{7}{|l|}{ D3 } \\
\hline & & 1 & 2 & 1 & 2 & 3 & 1 & 2 & 3 & 4 & 5 & 6 & 7 \\
\hline \multirow{3}{*}{$0-1$} & $\mathrm{n}$ & 1.632 & \begin{tabular}{|l|}
429 \\
\end{tabular} & 537 & 654 & 870 & 466 & 407 & 308 & 260 & 227 & 199 & 194 \\
\hline & $\%(\mathrm{C})$ & 79,18 & 20,82 & 26,06 & 31,73 & 42,21 & 22,61 & 19,75 & 14,94 & 12,62 & 11,01 & 9,66 & 9,41 \\
\hline & $\%(\mathrm{~K})$ & 5,56 & 1,45 & 2,79 & 3,40 & 4,52 & 5,65 & 4,93 & 3,73 & 3,15 & 2,75 & 2,41 & 2,35 \\
\hline \multirow{3}{*}{$1-2$} & $\mathrm{n}$ & 1.680 & 486 & 796 & 468 & 902 & 349 & 303 & 333 & 314 & 286 & 295 & 286 \\
\hline & $\%(\mathrm{C})$ & 81,51 & 23,58 & 38,62 & 22,71 & 43,77 & 16,93 & 14,70 & 16,16 & 15,24 & 13,88 & 14,31 & 13,88 \\
\hline & $\%(\mathrm{~K})$ & 5,72 & 1,65 & 4,14 & 2,43 & 4,69 & 4,23 & 3,67 & 4,04 & 3,81 & 3,47 & 3,58 & 3,47 \\
\hline \multirow{3}{*}{$2-3$} & $\mathrm{n}$ & 17.823 & 13.484 & 15.082 & 9.074 & 7.151 & 4.193 & 4.034 & 3.958 & 4.139 & 4.558 & 5.013 & 5.412 \\
\hline & $\%(\mathrm{C})$ & 56,93 & 43,07 & 48,17 & 28,98 & 22,84 & 13,39 & 12,89 & 12,64 & 13,22 & 14,56 & 16,01 & 17,29 \\
\hline & $\%(\mathrm{~K})$ & 60,70 & 45,73 & 78,35 & 47,14 & 37,15 & 50,82 & 48,90 & 47,98 & 50,17 & 55,25 & 60,76 & 65,60 \\
\hline \multirow{3}{*}{$3-4$} & $\mathrm{n}$ & 3.217 & 4.488 & 1.544 & 2.795 & 2.266 & 1.006 & 923 & 1.037 & 1.037 & 1.021 & 861 & 720 \\
\hline & $\%(\mathrm{C})$ & 41,75 & 58,25 & 20,04 & 36,28 & 29,41 & 13,06 & 11,98 & 13,46 & 13,46 & 13,25 & 11,17 & 9,34 \\
\hline & $\%(\mathrm{~K})$ & 10,96 & 15,22 & 8,02 & 14,52 & 11,77 & 12,19 & 11,19 & 12,57 & 12,57 & 12,38 & 10,44 & 8,73 \\
\hline \multirow{3}{*}{$4-5$} & $\mathrm{n}$ & 2.274 & 3.248 & 971 & 2.542 & 2.009 & 811 & 884 & 922 & 929 & 833 & 643 & 500 \\
\hline & $\%(\mathrm{C})$ & 41,18 & 58,82 & 17,58 & 46,03 & 36,38 & 14,69 & 16,01 & 16,70 & 16,82 & 15,09 & 11,64 & 9,05 \\
\hline & $\%(\mathrm{~K})$ & 7,74 & 11,02 & 5,04 & 13,21 & 10,44 & 9,83 & 10,72 & 11,18 & 11,26 & 10,10 & 7,79 & 6,06 \\
\hline \multirow{3}{*}{ 5-6 } & $\mathrm{n}$ & 1.375 & 2.746 & 266 & 1.8 & 2.051 & 606 & 626 & 633 & & 564 & 477 & 466 \\
\hline & $\%(\mathrm{C})$ & 33,37 & 66,63 & 6,45 & 43,78 & 49,77 & 14,71 & 15,19 & 15,36 & 18,18 & 13,69 & 11,57 & 11,31 \\
\hline & $\%(\mathrm{~K})$ & 4,68 & 9,31 & 1,38 & 9,37 & 10,65 & 7,35 & 7,59 & 7,67 & 9,08 & 6,84 & 5,78 & 5,65 \\
\hline \multirow{3}{*}{$6-7$} & $\mathrm{n}$ & 985 & 2.132 & 42 & 418 & 2.657 & 512 & 603 & 617 & 418 & 343 & 347 & 277 \\
\hline & $\%(\mathrm{C})$ & 31,60 & 68,40 & 1,35 & 13,41 & 85,24 & 16,43 & 19,35 & 19,79 & 13,41 & 11,00 & 11,13 & 8,89 \\
\hline & $\%(\mathrm{~K})$ & 3,35 & 7,23 & 0,22 & 2,17 & 13,80 & 6,21 & 7,31 & 7,48 & 5,07 & 4,16 & 4,21 & 3,36 \\
\hline \multirow{3}{*}{$7-8$} & $\mathrm{n}$ & 223 & 730 & 12 & 315 & 626 & 13 & 202 & 14 & & 92 & 124 & 129 \\
\hline & $\%(\mathrm{C})$ & 23,40 & 76,60 & 1,26 & 33,05 & 65,69 & 14,48 & 21,20 & 15,53 & 12,59 & 9,65 & 13,01 & 13,54 \\
\hline & $\%(\mathrm{~K})$ & 0,76 & 2,48 & 0,06 & 1,64 & 3,25 & 1,67 & 2,45 & 1,7 & 45 & 1,12 & 1,50 & 1,56 \\
\hline \multirow{3}{*}{$8-9$} & $\mathrm{n}$ & 130 & 558 & 0 & 25 & 42 & 96 & 141 & 12 & 55 & 95 & 10 & 77 \\
\hline & $\%(\mathrm{C})$ & 18,90 & 81,10 & 0,00 & 37,65 & 62,35 & 13,95 & 20,49 & 17,44 & 7,99 & 13,81 & 15 , & 11,19 \\
\hline & $\%(\mathrm{~K})$ & 0,44 & 1,89 & 0,00 & 1,35 & 2,23 & 1,16 & 1,71 & 1,45 & 0,67 & 1,15 & 1,26 & 0,93 \\
\hline \multirow{3}{*}{$9-10$} & $\mathrm{n}$ & 25 & 391 & 0 & 249 & 167 & 43 & 62 & 70 & 71 & 78 & 43 & 49 \\
\hline & $\%(\mathrm{C})$ & 6,01 & 93,99 & 0,00 & 59,86 & 40,14 & 10,34 & 14,90 & 16,83 & 17,07 & 18,75 & 10,34 & 11,78 \\
\hline & $\%(\mathrm{~K})$ & 0,09 & 1,33 & 0,00 & 1,29 & 0,87 & 0,52 & 0,75 & 0,85 & 0,86 & 0,95 & 0,52 & 0,59 \\
\hline \multirow{3}{*}{$10-11$} & $\mathrm{n}$ & 0 & 309 & 0 & 208 & 101 & 16 & 26 & 33 & 74 & 49 & 45 & 66 \\
\hline & $\%(\mathrm{C})$ & 0,00 & 100,00 & $0,0 \mathrm{C}$ & 67,31 & 32,69 & 5,18 & 8,41 & 10,6 & 23,95 & 15,86 & 14,56 & 21,36 \\
\hline & $\%(\mathrm{~K})$ & 0,00 & 1,05 & 0,00 & 1,08 & 0,52 & 0,19 & 0,32 & 0,40 & 0,90 & 0,59 & 0,55 & 0,80 \\
\hline \multirow{3}{*}{$11-12$} & $\mathrm{n}$ & 0 & 237 & 0 & 21 & 21 & 14 & 22 & 32 & 34 & 47 & 51 & 37 \\
\hline & $\%(\mathrm{C})$ & 0,00 & 100,00 & 0,00 & 91,14 & 8,86 & 5,91 & 9,28 & 13,50 & 14,35 & 19,83 & 21,52 & 15,61 \\
\hline & $\%(\mathrm{~K})$ & 0,00 & 0,80 & 0,00 & 1,12 & 0,11 & 0,17 & 0,27 & 0,39 & 0,41 & 0,57 & 0,62 & 0,45 \\
\hline \multirow{3}{*}{$12-13$} & $\mathrm{n}$ & 0 & 169 & 0 & 169 & 0 & 0 & 11 & 20 & 19 & 46 & 38 & 35 \\
\hline & $\%(\mathrm{C})$ & 0,00 & 100,00 & 0,00 & 100,00 & 0,00 & 0,00 & 6,51 & 11,83 & 11,24 & 27,22 & 22,49 & 20,71 \\
\hline & $\%(\mathrm{~K})$ & 0,00 & 0,57 & 0,00 & 0,88 & 0,00 & 0,00 & 0,13 & 0,24 & 0,23 & 0,56 & 0,46 & 0,42 \\
\hline \multirow{3}{*}{$13-14$} & $\mathrm{n}$ & 0 & 62 & 0 & 62 & 0 & 0 & 6 & 7 & 26 & 11 & 10 & 2 \\
\hline & $\%(\mathrm{C})$ & 0,00 & 100,00 & 0,0 & 100,00 & 0,0 & 0,00 & 9,6 & 11,29 & 41,94 & 17,74 & 16,13 & 3,23 \\
\hline & $\%(\mathrm{~K})$ & 0,00 & 0,21 & 0,00 & 0,32 & 0,00 & 0,00 & 0,07 & 0,08 & 0,32 & 0,13 & 0,12 & 0,02 \\
\hline & $\mathrm{n}$ & 0 & 14 & 0 & 14 & 0 & 0 & 0 & 9 & 5 & 0 & 0 & 0 \\
\hline $14-15$ & $\%(\mathrm{C})$ & 0,00 & 100,00 & 0,00 & 100,00 & 0,00 & 0,00 & 0,00 & 64,29 & 35,71 & 0,00 & 0,00 & 0,00 \\
\hline & $\%(\mathrm{~K})$ & 0,00 & 0,05 & 0,00 & 0,07 & 0,00 & 0,00 & 0,00 & 0,11 & 0,06 & 0,00 & 0,00 & 0,00 \\
\hline & $\mathrm{n}$ & 0 & 3 & 0 & 3 & 0 & 0 & 0 & 3 & 0 & 0 & 0 & 0 \\
\hline $15-16$ & $\%(\mathrm{C})$ & 0,00 & 100,00 & 0,00 & 100,00 & 0,00 & 0,00 & 0,00 & 100,00 & 0,00 & 0,00 & 0,00 & 0,00 \\
\hline & $\%(\mathrm{~K})$ & 0,00 & 0,01 & 0,00 & 0,02 & 0,00 & 0,00 & 0,00 & 0,04 & 0,00 & 0,00 & 0,00 & 0,00 \\
\hline
\end{tabular}


Table 4. Sub-categories and temperature change forecast values - rates total difference

\begin{tabular}{|c|c|c|c|c|c|c|c|c|c|c|c|c|}
\hline & \multicolumn{11}{|l|}{ D4 } \\
\hline & & 1 & 2 & 3 & 4 & 5 & 6 & 7 & 8 & 9 & 10 & 11 \\
\hline \multirow{3}{*}{$0-1$} & $\mathrm{n}$ & 325 & 223 & 142 & 86 & 53 & 48 & 63 & 128 & 218 & 284 & 491 \\
\hline & $\%(\mathrm{C})$ & 15.77 & 10.82 & 6.89 & 4.17 & 2.57 & 2.33 & 3.06 & 6.21 & 10.58 & 13.78 & 23.82 \\
\hline & $\%(\mathrm{~K})$ & 6.19 & 4.25 & 2.70 & 1.64 & 1.01 & 0.91 & 1.20 & 2.44 & 4.15 & 5.41 & 9.35 \\
\hline \multirow{3}{*}{$1-2$} & $\mathrm{n}$ & 241 & 208 & 162 & 139 & 123 & 130 & 183 & 196 & 240 & 307 & 237 \\
\hline & $\%(\mathrm{C})$ & 11.69 & 10.09 & 7.86 & 6.74 & 5.97 & 6.31 & 8.88 & 9.51 & 11.64 & 14.90 & 11.50 \\
\hline & $\%(\mathrm{~K})$ & 4.59 & 3.96 & 3.09 & 2.65 & 2.34 & 2.48 & 3.49 & 3.73 & 4.57 & 5.85 & 4.51 \\
\hline \multirow{3}{*}{$2-3$} & $\mathrm{n}$ & 2.801 & 2.889 & 2.972 & 2.996 & 3.019 & 3.015 & 2.941 & 2.856 & 2.717 & 2.588 & 2.513 \\
\hline & $\%(\mathrm{C})$ & 8.95 & 9.23 & 9.49 & 9.57 & 9.64 & 9.63 & 9.39 & 9.12 & 8.68 & 8.27 & 8.03 \\
\hline & $\%(\mathrm{~K})$ & 53.35 & 55.03 & 56.61 & 57.07 & 57.50 & 57.43 & 56.02 & 54.40 & 51.75 & 49.30 & 47.87 \\
\hline \multirow{3}{*}{$3-4$} & $\mathrm{n}$ & 485 & 478 & 505 & 591 & 584 & 558 & 615 & 643 & 696 & 734 & 716 \\
\hline & $\%(\mathrm{C})$ & 6.29 & 6.20 & 6.55 & 7.67 & 7.58 & 7.24 & 7.98 & 8.35 & 9.03 & 9.53 & 9.29 \\
\hline & $\%(\mathrm{~K})$ & 9.24 & 9.10 & 9.62 & 11.26 & 11.12 & 10.63 & 11.71 & 12.25 & 13.26 & 13.98 & 13.64 \\
\hline \multirow{3}{*}{$4-5$} & $\mathrm{n}$ & 387 & 417 & 484 & 439 & 462 & 537 & 515 & 545 & 555 & 576 & 605 \\
\hline & $\%(\mathrm{C})$ & 7.01 & 7.55 & 8.76 & 7.95 & 8.37 & 9.72 & 9.33 & 9.87 & 10.05 & 10.43 & 10.96 \\
\hline & $\%(\mathrm{~K})$ & 7.37 & 7.94 & 9.22 & 8.36 & 8.80 & 10.23 & 9.81 & 10.38 & 10.57 & 10.97 & 11.52 \\
\hline \multirow{3}{*}{$5-6$} & $\mathrm{n}$ & 392 & 445 & 356 & 346 & 406 & 382 & 394 & 364 & 352 & 366 & 318 \\
\hline & $\%(\mathrm{C})$ & 9.51 & 10.80 & 8.64 & 8.40 & 9.85 & 9.27 & 9.56 & 8.83 & 8.54 & 8.88 & 7.72 \\
\hline & $\%(\mathrm{~K})$ & 7.47 & 8.48 & 6.78 & 6.59 & 7.73 & 7.28 & 7.50 & 6.93 & 6.70 & 6.97 & 6.06 \\
\hline \multirow{3}{*}{$6-7$} & $\mathrm{n}$ & 346 & 289 & 278 & 308 & 294 & 284 & 248 & 280 & 277 & 263 & 250 \\
\hline & $\%(\mathrm{C})$ & 11.10 & 9.27 & 8.92 & 9.88 & 9.43 & 9.11 & 7.96 & 8.98 & 8.89 & 8.44 & 8.02 \\
\hline & $\%(\mathrm{~K})$ & 6.59 & 5.50 & 5.30 & 5.87 & 5.60 & 5.41 & 4.72 & 5.33 & 5.28 & 5.01 & 4.76 \\
\hline \multirow{3}{*}{$7-8$} & $\mathrm{n}$ & 102 & 87 & 109 & 102 & 75 & 76 & 105 & 82 & 96 & 66 & 53 \\
\hline & $\%(\mathrm{C})$ & 10.70 & 9.13 & 11.44 & 10.70 & 7.87 & 7.97 & 11.02 & 8.60 & 10.07 & 6.93 & 5.56 \\
\hline & $\%(\mathrm{~K})$ & 1.94 & 1.66 & 2.08 & 1.94 & 1.43 & 1.45 & 2.00 & 1.56 & 1.83 & 1.26 & 1.01 \\
\hline \multirow{3}{*}{$8-9$} & $\mathrm{n}$ & 62 & 74 & 96 & 68 & 60 & 67 & 55 & 66 & 60 & 39 & 41 \\
\hline & $\%(\mathrm{C})$ & 9.01 & 10.76 & 13.95 & 9.88 & 8.72 & 9.74 & 7.99 & 9.59 & 8.72 & 5.67 & 5.96 \\
\hline & $\%(\mathrm{~K})$ & 1.18 & 1.41 & 1.83 & 1.30 & 1.14 & 1.28 & 1.05 & 1.26 & 1.14 & 0.74 & 0.78 \\
\hline \multirow{3}{*}{$9-10$} & $\mathrm{n}$ & 54 & 56 & 34 & 53 & 47 & 40 & 41 & 48 & 25 & 11 & 7 \\
\hline & $\%(\mathrm{C})$ & 12.98 & 13.46 & 8.17 & 12.74 & 11.30 & 9.62 & 9.86 & 11.54 & 6.01 & 2.64 & 1.68 \\
\hline & $\%(\mathrm{~K})$ & 1.03 & 1.07 & 0.65 & 1.01 & 0.90 & 0.76 & 0.78 & 0.91 & 0.48 & 0.21 & 0.13 \\
\hline \multirow{3}{*}{$10-11$} & $\mathrm{n}$ & 29 & 37 & 30 & 31 & 34 & 35 & 38 & 30 & 11 & 15 & 19 \\
\hline & $\%(\mathrm{C})$ & 9.39 & 11.97 & 9.71 & 10.03 & 11.00 & 11.33 & 12.30 & 9.71 & 3.56 & 4.85 & 6.15 \\
\hline & $\%(\mathrm{~K})$ & 0.55 & 0.70 & 0.57 & 0.59 & 0.65 & 0.67 & 0.72 & 0.57 & 0.21 & 0.29 & 0.36 \\
\hline \multirow{3}{*}{$11-12$} & $\mathrm{n}$ & 14 & 26 & 40 & 37 & 33 & 35 & 36 & 12 & 3 & 1 & 0 \\
\hline & $\%(\mathrm{C})$ & 5.91 & 10.97 & 16.88 & 15.61 & 13.92 & 14.77 & 15.19 & 5.06 & 1.27 & 0.42 & 0.00 \\
\hline & $\%(\mathrm{~K})$ & 0.27 & 0.50 & 0.76 & 0.70 & 0.63 & 0.67 & 0.69 & 0.23 & 0.06 & 0.02 & 0.00 \\
\hline \multirow{3}{*}{$12-13$} & $\mathrm{n}$ & 7 & 12 & 32 & 37 & 40 & 29 & 12 & 0 & 0 & 0 & 0 \\
\hline & $\%(\mathrm{C})$ & 4.14 & 7.10 & 18.93 & 21.89 & 23.67 & 17.16 & 7.10 & 0.00 & 0.00 & 0.00 & 0.00 \\
\hline & $\%(\mathrm{~K})$ & 0.13 & 0.23 & 0.61 & 0.70 & 0.76 & 0.55 & 0.23 & 0.00 & 0.00 & 0.00 & 0.00 \\
\hline \multirow{3}{*}{$13-14$} & $\mathrm{n}$ & 5 & 9 & 10 & 11 & 13 & 10 & 4 & 0 & 0 & 0 & 0 \\
\hline & $\%(\mathrm{C})$ & 8.06 & 14.52 & 16.13 & 17.74 & 20.97 & 16.13 & 6.45 & 0.00 & 0.00 & 0.00 & 0.00 \\
\hline & $\%(\mathrm{~K})$ & 0.10 & 0.17 & 0.19 & 0.21 & 0.25 & 0.19 & 0.08 & 0.00 & 0.00 & 0.00 & 0.00 \\
\hline \multirow{3}{*}{$14-15$} & $\mathrm{n}$ & 0 & 0 & 0 & 6 & 4 & 4 & 0 & 0 & 0 & 0 & 0 \\
\hline & $\%(\mathrm{C})$ & 0.00 & 0.00 & 0.00 & 42.86 & 28.57 & 28.57 & 0.00 & 0.00 & 0.00 & 0.00 & 0.00 \\
\hline & $\%(\mathrm{~K})$ & 0.00 & 0.00 & 0.00 & 0.11 & 0.08 & 0.08 & 0.00 & 0.00 & 0.00 & 0.00 & 0.00 \\
\hline \multirow{3}{*}{$15-16$} & $\mathrm{n}$ & 0 & 0 & 0 & 0 & 3 & 0 & 0 & 0 & 0 & 0 & 0 \\
\hline & $\%(\mathrm{C})$ & 0.00 & 0.00 & 0.00 & 0.00 & 100.00 & 0.00 & 0.00 & 0.00 & 0.00 & 0.00 & 0.00 \\
\hline & $\%(\mathrm{~K})$ & 0.00 & 0.00 & 0.00 & 0.00 & 0.06 & 0.00 & 0.00 & 0.00 & 0.00 & 0.00 & 0.00 \\
\hline
\end{tabular}


Table 4. Sub-categories and temperature change forecast values - rates total difference

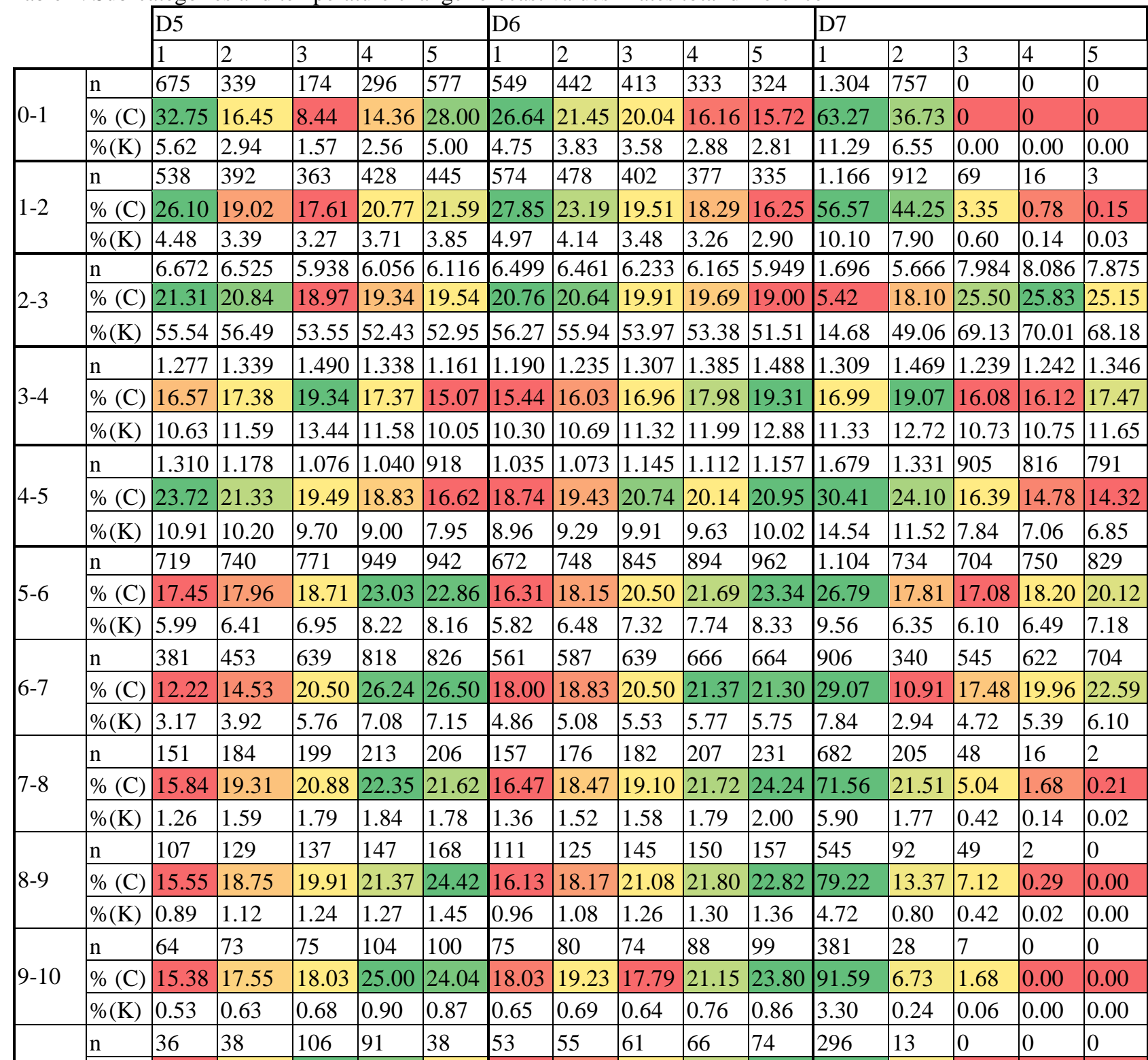

\begin{tabular}{|l|l|l|l|l|l|l|l|l|l|l|l|l|l|l|l|l|}
\hline $10-11$ & $\%(\mathrm{C})$ & 11.65 & 12.30 & 34.30 & 29.45 & 12.30 & 17.15 & 17.80 & 19.74 & 21.36 & 23.95 & 95.79 & 4.21 & 0.00 & 0.00 & 0.00 \\
\cline { 2 - 11 }
\end{tabular} \begin{tabular}{|l|l|l|l|l|l|l|l|l|l|l|l|l|l|l|l|}
\hline$\%(\mathrm{~K})$ & 0.30 & 0.33 & 0.96 & 0.79 & 0.33 & 0.46 & 0.48 & 0.53 & 0.57 & 0.64 & 2.56 & 0.11 & 0.00 & 0.00 & 0.00 \\
\hline
\end{tabular} \begin{tabular}{|l|l|l|l|l|l|l|l|l|l|l|l|l|l|l|l|}
$\mathrm{n}$ & 37 & 62 & 70 & 40 & 28 & 48 & 45 & 52 & 44 & 48 & 234 & 3 & 0 & 0 & 0 \\
\hline
\end{tabular}

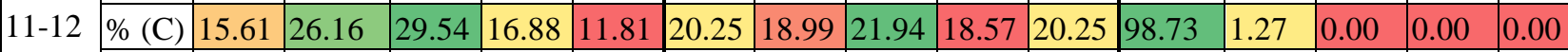

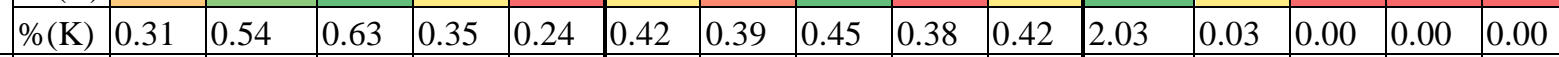

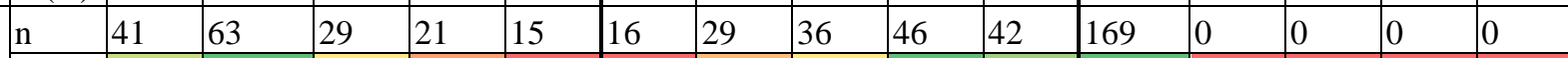

\begin{tabular}{|l|l|l|l|l|l|l|l|l|l|l|l|l|l|l|l|l|l|l|l|}
\hline $12-13$ & $\%(\mathrm{C})$ & 24.26 & 37.28 & 17.16 & 12.43 & 8.88 & 9.47 & 17.16 & 21.30 & 27.22 & 24.85 & 100.00 & 0.00 & 0.00 & 0.00 & 0.00 \\
\hline
\end{tabular} \begin{tabular}{|l|l|l|l|l|l|l|l|l|l|l|l|l|l|l|l|}
\hline$\%(\mathrm{~K})$ & 0.34 & 0.55 & 0.26 & 0.18 & 0.13 & 0.14 & 0.25 & 0.31 & 0.40 & 0.36 & 1.46 & 0.00 & 0.00 & 0.00 & 0.00 \\
\hline
\end{tabular}

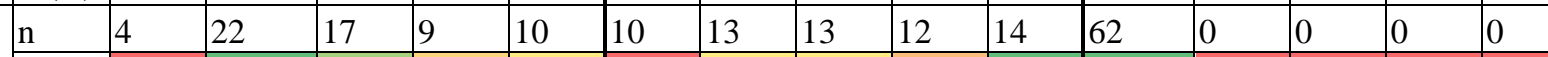

\begin{tabular}{|l|l|l|l|l|l|l|l|l|l|l|l|l|l|l|l|l}
$13-14$ & $\%(\mathrm{C})$ & 6.45 & 35.48 & 27.42 & 14.52 & 16.13 & 16.13 & 20.97 & 20.97 & 19.35 & 22.58 & 100.00 & 0.00 & 0.00 & 0.00 & 0.00 \\
\hline
\end{tabular} \begin{tabular}{|l|l|l|l|l|l|l|l|l|l|l|l|l|l|l|l|}
\hline$\%(\mathrm{~K})$ & 0.03 & 0.19 & 0.15 & 0.08 & 0.09 & 0.09 & 0.11 & 0.11 & 0.10 & 0.12 & 0.54 & 0.00 & 0.00 & 0.00 & 0.00 \\
\hline
\end{tabular}

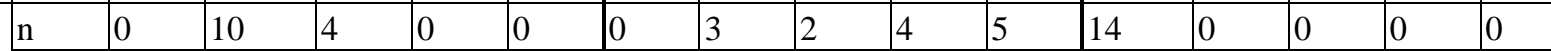

\begin{tabular}{|l|l|l|l|l|l|l|l|l|l|l|l|l|l|l|l|l|l|l|}
$14-15$ & $\%(\mathrm{C})$ & 0.00 & 71.43 & 28.57 & 0.00 & 0.00 & 0.00 & 21.43 & 14.29 & 28.57 & 35.71 & 100.00 & 0.00 & 0.00 & 0.00 & 0.00 \\
\hline
\end{tabular}

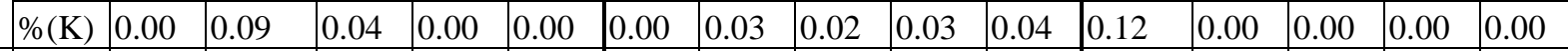
\begin{tabular}{|l|l|l|l|l|l|l|l|l|l|l|l|l|l|l|l|}
$\mathrm{n}$ & 0 & 3 & 0 & 0 & 0 & 0 & 0 & 1 & 1 & 1 & 3 & 0 & 0 & 0 & 0 \\
\hline
\end{tabular}

\begin{tabular}{|l|l|l|l|l|l|l|l|l|l|l|l|l|l|l|l|l|l|l|l|}
\hline \multirow{2}{*}{$15-16$} & $\%(\mathrm{C})$ & 0.00 & 100.00 & 0.00 & 0.00 & 0.00 & 0.00 & 0.00 & 33.33 & 33.33 & 33.33 & 100.00 & 0.00 & 0.00 & 0.00 & 0.00 \\
\cline { 2 - 13 }
\end{tabular}

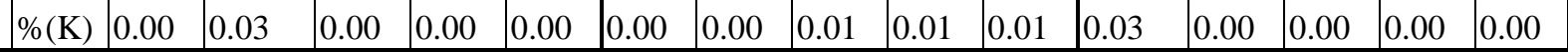


Table 5. Sub-categories and temperature change forecast values - rates for subcategories

\begin{tabular}{|c|c|c|c|c|c|c|c|c|c|c|c|c|c|c|c|c|}
\hline & \multicolumn{3}{|l|}{$0-1$} & \multicolumn{3}{|l|}{$1-2$} & \multicolumn{3}{|l|}{$2-3$} & \multicolumn{3}{|l|}{$3-4$} & \multicolumn{3}{|l|}{$4-5$} \\
\hline & & $\mathrm{n}$ & $\%(\mathrm{C})$ & $\%(\mathrm{~K})$ & $\mathrm{n}$ & $\%(\mathrm{C})$ & $\%(\mathrm{~K})$ & $\mathrm{n}$ & $\%(\mathrm{C})$ & $\%(\mathrm{~K})$ & $\mathrm{n}$ & $\%(\mathrm{C})$ & $\%(\mathrm{~K})$ & $\mathrm{n}$ & $\%(\mathrm{C})$ & $\%(\mathrm{~K})$ \\
\hline \multirow[b]{2}{*}{$\bar{\rho}$} & 1 & 1.632 & 79.18 & 5.56 & 1.680 & 81.51 & 5.72 & 17.823 & 56.93 & 60.70 & 3.217 & 41.75 & 10.96 & 2.274 & 41.18 & 7.74 \\
\hline & 2 & 429 & 20.82 & 1.45 & 486 & 23.58 & 1.65 & 13.484 & 43.07 & 45.73 & 4.488 & 58.25 & 15.22 & 3.248 & 58.82 & 11.02 \\
\hline \multirow[b]{3}{*}{ กิ } & 1 & 537 & 26.06 & 2.79 & 796 & 38.62 & 4.14 & 15.082 & 48.17 & 78.35 & 1.544 & 20.04 & 8.02 & 971 & 17.58 & 5.04 \\
\hline & 2 & 54 & 31.73 & 3.40 & 468 & 22.71 & 2.43 & 9.074 & 28.98 & 47.14 & 2.795 & 36.28 & 14.52 & 2.542 & 46.03 & 13.21 \\
\hline & 3 & 870 & 42.21 & 4.52 & 902 & 43.77 & 4.69 & 7.151 & 22.84 & 37.15 & 2.266 & 29.41 & 11.77 & 2.009 & 36.38 & 10.44 \\
\hline \multirow[b]{7}{*}{$\hat{\rho}$} & 1 & 466 & 22.61 & 5.65 & 349 & 16.93 & 4.23 & 4.193 & 13.39 & 50.82 & 1.006 & 13.06 & 12.19 & 811 & 14.69 & 9.83 \\
\hline & 2 & 407 & 19.75 & 4.93 & 303 & 14.70 & 3.67 & 4.034 & 12.89 & 48.90 & 923 & 11.98 & 11.19 & 884 & 16.01 & 10.72 \\
\hline & 3 & 308 & 14.94 & 3.73 & 333 & 16.16 & 4.04 & 3.958 & 12.64 & 47.98 & 1.037 & 13.46 & 12.57 & 922 & 16.70 & 11.18 \\
\hline & 4 & 260 & 12.62 & 3.15 & 314 & 15.24 & 3.81 & 4.139 & 13.22 & 50.17 & 1.037 & 13.46 & 12.57 & 929 & 16.82 & 11.26 \\
\hline & 5 & 227 & 11.01 & 2.75 & 286 & 13.88 & 3.47 & 4.558 & 14.56 & 55.25 & 1.021 & 13.25 & 12.38 & 833 & 15.09 & 10.10 \\
\hline & 6 & 199 & 9.66 & 2.41 & 295 & 14.31 & 3.58 & 5.013 & 16.01 & 60.76 & 861 & 11.17 & 10.44 & 643 & 11.64 & 7.79 \\
\hline & 7 & 194 & 9.41 & 2.35 & 286 & 13.88 & 3.47 & 5.412 & 17.29 & 65.60 & 720 & 9.34 & 8.73 & 500 & .05 & 6.06 \\
\hline \multirow[b]{11}{*}{$\stackrel{+}{\ominus}$} & 1 & 325 & 15.77 & 6.19 & 241 & 11.69 & 4.59 & 2.801 & 8.95 & 53.35 & 485 & 6.29 & 9.24 & 387 & 7.01 & 7.37 \\
\hline & 2 & 223 & 10.82 & 4.25 & 208 & 10.09 & 3.96 & 2.889 & 9.23 & 55.03 & 478 & 6.20 & 9.10 & 417 & 7.55 & 7.94 \\
\hline & 3 & 142 & 6.89 & 2.70 & 162 & 7.86 & 3.09 & 2.972 & 9.49 & 56.61 & 505 & & & 484 & & 9.22 \\
\hline & 4 & 86 & 4.17 & 1.64 & 139 & 6.74 & 2.65 & 2.996 & 9.57 & 57.07 & 591 & 7.67 & 11.26 & 439 & 7.95 & 8.36 \\
\hline & 5 & 53 & 2.57 & 1.01 & 123 & 5.97 & 2.34 & 3.019 & 9.64 & 57.50 & 584 & 7.58 & 11.12 & 462 & 8.37 & 8.80 \\
\hline & 6 & 48 & 2.33 & 0.91 & 130 & 6.31 & 2.48 & 15 & 9.63 & 57.43 & 558 & 7.24 & 10.63 & 537 & 9.72 & 10.23 \\
\hline & 7 & 63 & 3.06 & 1.20 & 183 & 8.88 & 3.49 & 2.941 & 9.39 & 56.02 & 615 & 7.98 & 11.71 & 515 & 9.33 & 9.81 \\
\hline & 8 & 128 & 6.21 & 2.44 & 196 & 9.51 & 3.73 & 2.856 & 9.12 & 54.40 & 643 & 8.35 & 12.25 & 545 & 9.87 & 10.38 \\
\hline & 9 & 218 & 10.58 & 4.15 & 240 & 11.64 & 4.57 & 2.717 & 8.68 & 51.75 & 696 & 9.03 & 13.26 & 555 & 10.05 & 10.57 \\
\hline & 10 & 284 & 13.78 & 5.41 & 307 & 14.90 & 5.85 & 2.588 & 8.27 & 49.30 & 734 & 9.53 & 13.98 & 576 & 10.43 & \begin{tabular}{|l}
10.97 \\
\end{tabular} \\
\hline & 11 & 491 & 23.82 & 9.35 & 237 & 11.50 & 4.51 & 2.513 & 8.03 & 47.87 & 716 & 9.29 & 13.64 & 605 & 10.96 & 11.52 \\
\hline \multirow[b]{5}{*}{$\stackrel{n}{n}$} & 1 & 675 & 32.75 & 5.62 & 538 & 26.10 & 4.48 & 6.672 & 21.31 & 55.54 & 1.277 & 16.57 & 10.63 & 1.310 & 23.72 & 10.91 \\
\hline & 2 & 339 & 16.45 & 2.94 & 392 & 19.02 & 3.39 & & 20.84 & 56.49 & 1.339 & 17.38 & 11.59 & 1.178 & 21.33 & 10.20 \\
\hline & 3 & 174 & 8.44 & 1.57 & 363 & 17.61 & 3.27 & 5.938 & 18.97 & 53.55 & 1.490 & 19.34 & 13.44 & 1.076 & 19.49 & 9.70 \\
\hline & 4 & 296 & 14.36 & 2.56 & 428 & 20.77 & 3.71 & 6.056 & 19.34 & 52.43 & 1.338 & 17.37 & 11.58 & 1.040 & 18.83 & 9.00 \\
\hline & 5 & 577 & 28.00 & 5.00 & 445 & 21.59 & 3.85 & 6.116 & 19.54 & 52.95 & 1.161 & 15.07 & 10.05 & 918 & 16.62 & 7.95 \\
\hline \multirow[b]{5}{*}{$\stackrel{\circ}{\varrho}$} & 1 & 549 & 26.64 & 4.75 & 574 & 27.85 & 4.97 & 6.499 & 20.76 & 56.27 & 1.190 & 15.44 & 10.30 & 1.035 & 18.74 & 8.96 \\
\hline & 2 & 442 & 21.45 & 3.83 & 478 & 23.19 & 4.14 & 6.461 & 20.64 & 55.94 & 1.235 & 16.03 & 10.69 & 1.073 & 19.43 & 9.29 \\
\hline & 3 & 413 & 20.04 & 3.58 & 402 & 19.51 & 3.48 & 6.233 & 19.91 & \begin{tabular}{|l}
53.97 \\
\end{tabular} & 1.307 & 16.96 & 11.32 & 1.145 & 20.74 & 9.91 \\
\hline & 4 & 333 & 16.16 & 2.88 & 377 & 18.29 & 3.26 & 6.165 & 19.69 & 53.38 & 1.385 & 17.98 & 11.99 & 1.112 & 20.14 & 9.63 \\
\hline & 5 & 324 & 15.72 & 2.81 & 335 & 16.25 & 2.90 & 5.949 & 19.00 & 51.51 & 1.488 & 19.31 & 12.88 & 1.157 & 20.95 & 10.02 \\
\hline \multirow[b]{5}{*}{$\hat{2}$} & 1 & 1.304 & 63.27 & 11.29 & 1.166 & 56.57 & 10.10 & 1.696 & 5.42 & 14.68 & 1.309 & 16.99 & 11.33 & 1.679 & 30.41 & 14.54 \\
\hline & 2 & 757 & 36.73 & 6.55 & 912 & 44.25 & 7.90 & 5.666 & 18.10 & 49.06 & 1.469 & 19.07 & 12.72 & 1.331 & 24.10 & 11.52 \\
\hline & 3 & 0 & 0.00 & 0.00 & 69 & 3.35 & 0.60 & 7.984 & 25.50 & 69.13 & 1.239 & 16.08 & 10.73 & 905 & 16.39 & 7.84 \\
\hline & 4 & 0 & 0.00 & 0.00 & 16 & 0.78 & 0.14 & 8.086 & 25.83 & 70.01 & 1.242 & 16.12 & 10.75 & 816 & 14.78 & 7.06 \\
\hline & 5 & 0 & 0.00 & 0.00 & 3 & 0.15 & 0.03 & 7.875 & 25.15 & 68.18 & 1.346 & 17.47 & 11.65 & 791 & 14.32 & 6.85 \\
\hline
\end{tabular}

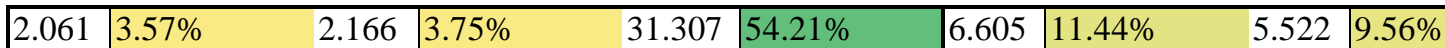

Table 5. Sub-categories and temperature change forecast values - rates for subcategories

\begin{tabular}{|c|c|c|c|c|c|c|c|c|c|c|c|c|c|c|c|c|}
\hline & \multicolumn{3}{|l|}{$5-6$} & \multicolumn{3}{|l|}{$6-7$} & \multicolumn{3}{|l|}{$7-8$} & \multicolumn{3}{|l|}{$8-9$} & \multicolumn{3}{|c|}{$9-10$} \\
\hline & & $\mathrm{n}$ & $\%(\mathrm{C})$ & $\%(\mathrm{~K})$ & $\mathrm{n}$ & $\%(\mathrm{C})$ & $\%(\mathrm{~K})$ & $\mathrm{n}$ & $\%(\mathrm{C})$ & $\%(\mathrm{~K})$ & $\mathrm{n}$ & $\%(\mathrm{C})$ & $\%(\mathrm{~K})$ & $\mathrm{n}$ & $\%(\mathrm{C})$ & $\%(\mathrm{~K})$ \\
\hline \multirow[b]{2}{*}{$\bar{\theta}$} & 1 & 1.375 & 33.37 & 4.68 & 985 & 31.60 & 3.35 & 223 & 23.40 & 0.76 & 130 & 18.90 & 0.44 & 25 & 6.01 & 0.09 \\
\hline & 2 & 2.746 & 66.63 & 9.31 & 2.132 & 68.40 & 7.23 & 730 & 76.60 & 2.48 & 558 & 81.10 & 1.89 & 391 & 93.99 & 1.33 \\
\hline \multirow[b]{3}{*}{ ฮิ } & 1 & 266 & 6.45 & 1.38 & 42 & 1.35 & 0.22 & 12 & 1.26 & 0.06 & 0 & 0.00 & 0.00 & 0 & 0.00 & 0.00 \\
\hline & 2 & 1.804 & 43.78 & 9.37 & 418 & 13.41 & 2.17 & 315 & 33.05 & 1.64 & 259 & 37.65 & 1.35 & 249 & 59.86 & 1.29 \\
\hline & 3 & 2.051 & 49.77 & 10.65 & 2.657 & 85.24 & 13.80 & 626 & 65.69 & 3.25 & 429 & 62.35 & 2.23 & 167 & 40.14 & 0.87 \\
\hline \multirow[b]{7}{*}{$\hat{\rho}$} & 1 & 606 & 14.71 & 7.35 & 512 & 16.43 & 6.21 & 138 & 14.48 & 1.67 & 96 & 13.95 & 1.16 & 43 & 10.34 & 0.52 \\
\hline & 2 & 626 & 15.19 & 7.59 & 603 & 19.35 & 7.31 & 202 & 21.20 & 2.45 & 141 & 20.49 & 1.71 & 62 & 14.90 & 0.75 \\
\hline & 3 & 633 & 15.36 & 7.67 & 617 & 19.79 & 7.48 & 148 & 15.53 & 1.79 & 120 & 17.44 & 1.45 & 70 & 16.83 & 0.85 \\
\hline & 4 & 749 & 18.18 & 9.08 & 418 & 13.41 & 5.07 & 120 & 12.59 & 1.45 & 55 & 7.99 & 0.67 & 71 & 17.07 & 0.86 \\
\hline & 5 & 564 & 13.69 & 6.84 & 343 & 11.00 & 4.16 & 92 & 9.65 & 1.12 & 95 & 13.81 & 1.15 & 78 & 18.75 & 0.95 \\
\hline & 6 & 477 & 11.57 & 5.78 & 347 & 11.13 & 4.21 & 124 & 13.01 & 1.50 & 104 & 15.12 & 1.26 & 43 & 10.34 & 0.52 \\
\hline & 7 & 466 & 11.31 & 5.65 & 277 & 8.89 & 3.36 & 129 & 13.54 & 1.56 & 77 & 11.19 & 0.93 & 49 & 11.78 & 0.59 \\
\hline
\end{tabular}


Table 5. Sub-categories and temperature change forecast values - rates for subcategories

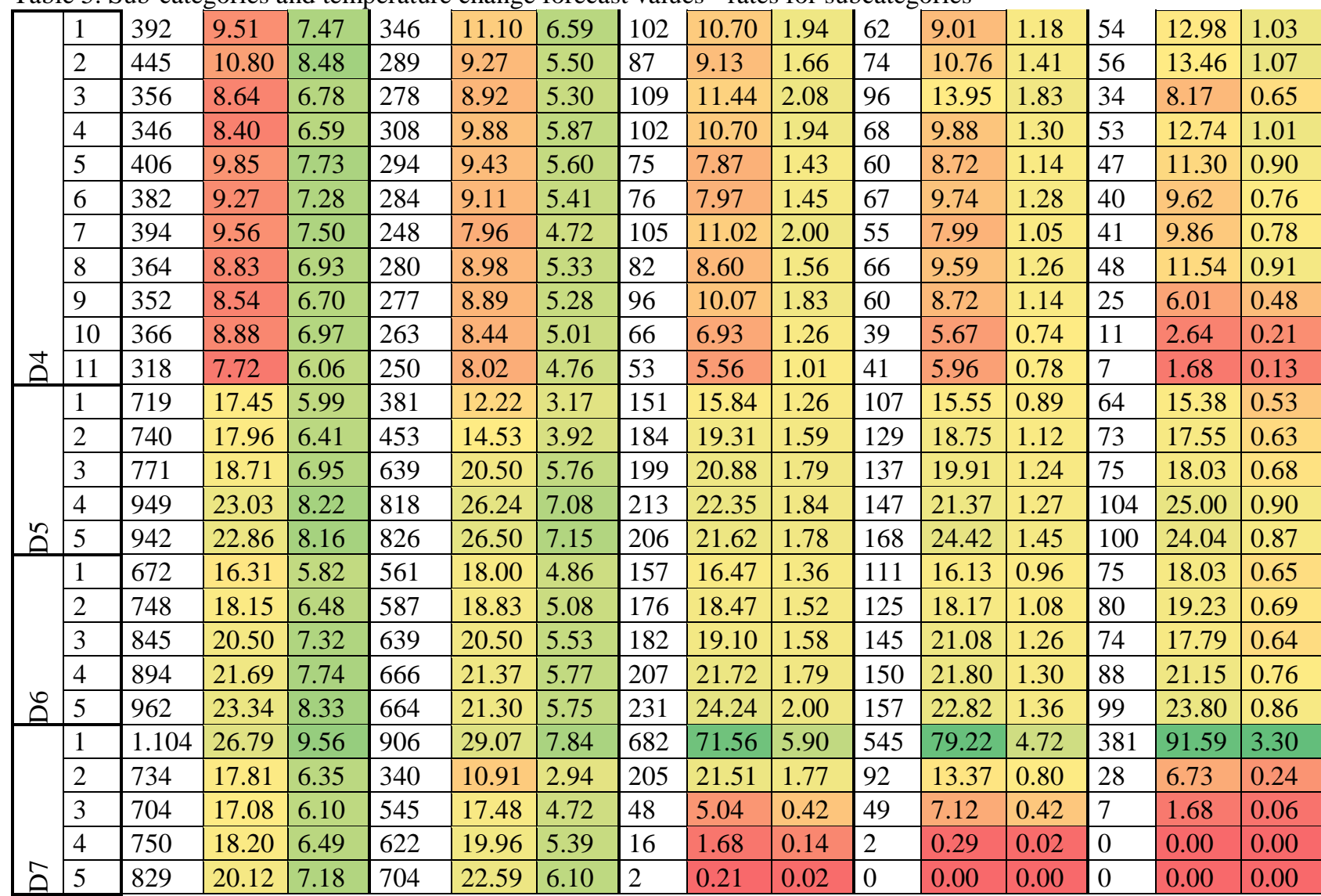

\begin{tabular}{|l|ll|ll|ll|ll|l|}
\hline 4.121 & $7.14 \%$ & 3.117 & $5.40 \%$ & 953 & $1.65 \%$ & 688 & $1.19 \%$ & 416 & $0.72 \%$ \\
\hline
\end{tabular}

Table 5. Sub-categories and temperature change forecast values - rates for subcategories

\begin{tabular}{|l|l|l|l|l|l|}
\hline $10-11$ & $11-12$ & $13-14$ & 13
\end{tabular}

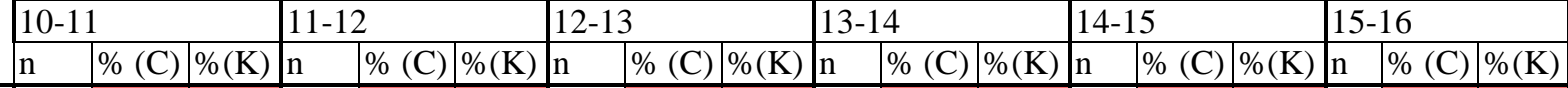

\begin{tabular}{|c|c|c|c|c|c|c|c|c|c|c|c|c|c|c|c|c|c|c|c|}
\hline & 1 & 0 & .00 & 0.00 & 0 & 0.00 & 0.00 & 0 & .00 & 0.00 & 0 & 00 & 0.00 & 0 & 0.00 & 00 & & 0.00 & \\
\hline $\bar{\theta}$ & 2 & 309 & 100 & 1.05 & 237 & 100 & 0.80 & 169 & 100 & & 62 & & 021 & 14 & 100 & 0.05 & & 100 & 01 \\
\hline \multirow[b]{3}{*}{$\tilde{\varepsilon}$} & 1 & 0 & & & 0 & & .00 & & & & & & 0.00 & & 0.00 & 0.00 & & .00 & .00 \\
\hline & 2 & 08 & 7.31 & 1.08 & 216 & 91.14 & 1.12 & 69 & 00 & 0.88 & & 00 & 0.32 & & 100 & .07 & & 100 & 0.02 \\
\hline & 3 & & 32.69 & 0.52 & 21 & 8.86 & 0.11 & & 0.00 & 0.00 & & 0.00 & 0.00 & $\Omega_{0}$ & 0.00 & 0.00 & & 0.00 & 0.00 \\
\hline & 1 & & 5.18 & 0.19 & 17 & 5.91 & 0.17 & & 0.00 & 0.00 & & 0.00 & 0.00 & & 0.00 & 0.00 & & 0.00 & 0.00 \\
\hline & 2 & & 8.41 & 0.32 & $2-$ & 9.28 & 0.27 & 11 & 6.51 & 0.13 & & & 007 & & 0.00 & 0.00 & & 0.00 & 0.00 \\
\hline & 3 & 33 & 10.68 & 0.40 & 32 & 13.50 & 0.39 & 20 & 11.8 & 0.24 & & 11.29 & 0.08 & & 64.29 & 0.11 & & 100 & 0.04 \\
\hline & 4 & 74 & 23.95 & 0.90 & 34 & 14.35 & 0.41 & 19 & 11.24 & 0.23 & 26 & 41.94 & 0.32 & & 35.71 & 0.06 & & 0.00 & 0.00 \\
\hline & 5 & 49 & .86 & .59 & 47 & 19.83 & 0.57 & 46 & 27.22 & 0.56 & 11 & 17.74 & 0.13 & 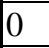 & 0.00 & 0.00 & & 0.00 & 0.00 \\
\hline & 6 & 45 & 14.56 & 0.55 & 51 & 21.52 & 0.62 & 38 & 22.4 & 0.46 & 10 & & 0.12 & 0 & & 0.00 & & & 0.00 \\
\hline & 7 & 66 & 21.36 & 0.80 & 37 & 15.61 & 0.45 & 35 & 20.71 & 0.42 & 2 & 3.23 & 0.02 & 0 & 0.00 & 0.00 & & 0.00 & 0.00 \\
\hline \multirow[b]{11}{*}{ 苞 } & 1 & 29 & 9.39 & 0.55 & 14 & 5.91 & 0.27 & & 4.14 & 0.13 & & 8.06 & 0.10 & 0 & 0.00 & 0.00 & & 0.00 & 0.00 \\
\hline & 2 & 37 & .97 & 0 & 26 & 10. & 0.50 & 12 & 7.10 & 0.23 & 9 & & 0.17 & 0 & & 0.00 & & & 0.00 \\
\hline & 3 & 30 & 9.71 & 0.57 & 40 & 16.88 & 0.76 & 32 & 18.93 & 0.61 & 10 & 16.13 & 0.19 & $\Omega_{2}$ & 0.00 & 0.00 & & 0.00 & 0.00 \\
\hline & 4 & 31 & 10.03 & 0.59 & 37 & 15.61 & 0.70 & 37 & 21.89 & 0.70 & 11 & 17.74 & 0.21 & 6 & 42.86 & 0.11 & & 0.00 & 0.00 \\
\hline & 5 & 34 & 11.00 & 0.65 & 33 & 13.92 & 0.63 & 40 & 23.67 & 0.76 & 3 & 20.97 & 0.25 & 4 & 28.57 & 0.08 & & 100 & 0.06 \\
\hline & 6 & 35 & 11.33 & 0.67 & 35 & 14.77 & 0.67 & 29 & 17.16 & 0.55 & 10 & 16.13 & 0.19 & 4 & 28.57 & 0.08 & & 0.00 & 0.00 \\
\hline & 7 & 38 & 12.30 & 0.72 & 36 & 15.19 & 0.69 & 12 & 7.10 & 0.23 & 4 & 6.45 & 0.08 & 0 & 0.00 & 0.00 & & 0.00 & 0.00 \\
\hline & 8 & 30 & 9.71 & 0.57 & 12 & 5.06 & 0.23 & 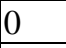 & 0.00 & 0.00 & 0 & 0.00 & 0.00 & 0 & 0.00 & 0.00 & & 0.00 & 0.00 \\
\hline & 9 & 11 & 3.56 & 0.21 & 3 & 1.27 & 0.06 & 0 & 0.00 & 0.00 & 0 & 0.00 & 0.00 & 0 & 0.00 & 0.00 & & 0.00 & 0.00 \\
\hline & 10 & 15 & 4.85 & 0.29 & 1 & 0.42 & 0.02 & 0 & 0.00 & 0.00 & 0 & 0.00 & 0.00 & 0 & 0.00 & 0.00 & & 0.00 & 0.00 \\
\hline & 11 & 19 & 6.15 & 0.36 & 0 & 0.00 & 0.00 & 0 & 0.00 & 0.00 & 0 & 0.00 & 0.00 & 0 & 0.00 & 0.00 & 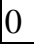 & 0.00 & 0.00 \\
\hline
\end{tabular}


Table 5. Sub-categories and temperature change forecast values - rates for subcategories

\begin{tabular}{|l|l|l|l|l|l|l|l|l|l|l|l|l|l|l|l|l|l|l|l|}
\hline & 1 & 36 & 11.65 & 0.30 & 37 & 15.61 & 0.31 & 41 & 24.26 & 0.34 & 4 & 6.45 & 0.03 & 0 & 0.00 & 0.00 & 0 & 0.00 & 0.00 \\
\hline 2 & 38 & 12.30 & 0.33 & 62 & 26.16 & 0.54 & 63 & 37.28 & 0.55 & 22 & 35.48 & 0.19 & 10 & 71.43 & 0.09 & 3 & 100 & 0.03 \\
\hline \multirow{4}{*}{3} & 106 & 34.30 & 0.96 & 70 & 29.54 & 0.63 & 29 & 17.16 & 0.26 & 17 & 27.42 & 0.15 & 4 & 28.57 & 0.04 & 0 & 0.00 & 0.00 \\
\hline \multirow{4}{*}{} & 91 & 29.45 & 0.79 & 40 & 16.88 & 0.35 & 21 & 12.43 & 0.18 & 9 & 14.52 & 0.08 & 0 & 0.00 & 0.00 & 0 & 0.00 & 0.00 \\
\hline & 5 & 38 & 12.30 & 0.33 & 28 & 11.81 & 0.24 & 15 & 8.88 & 0.13 & 10 & 16.13 & 0.09 & 0 & 0.00 & 0.00 & 0 & 0.00 & 0.00 \\
\hline
\end{tabular}

\begin{tabular}{|c|c|c|c|c|c|c|c|c|c|c|c|c|c|c|c|c|c|c|c|}
\hline & 1 & & & & & & & & & & 0 & & & & 0.00 & & & $\overline{0.00}$ & \\
\hline & 2 & 55 & .80 & 48 & & 18.99 & 0.39 & & 17.16 & ln? & 13 & & 0.11 & & 21.43 & & & & \\
\hline & 3 & 61 & .74 & 53 & & 21.94 & 0.45 & & & 0.3 & 13 & & & & & & & & \\
\hline & 4 & 66 & .36 & 57 & & 18.57 & 0.38 & & 27. & 0.4 & 12 & & & & & & & 3. & \\
\hline 气 & 5 & 74 & & & & .25 & & & 24. & 0. & 14 & & & & & & & $33 .$. & \\
\hline & 1 & 296 & 95.79 & & & 98.73 & & & 10 & & 62 & & & & 10 & & & 10 & \\
\hline & 2 & 13 & 4.21 & 0. & & 1.27 & & & & .0 & 0 & & & & & & & & 0.1 \\
\hline & 3 & 0 & 0.00 & .00 & & & & & & 0.1 & & & & & & 0. & & & 0.1 \\
\hline & 4 & 0 & 0.00 & 0.00 & & & & & & 0.1 & & & & & & 0 . & & 0.00 & 0.00 \\
\hline 3 & & & 0.00 & 0.00 & U & 0.00 & 0.00 & & 0.00 & 0.00 & 0 & 0.00 & 0.00 & & 0.00 & 0.00 & & 0.00 & 0.00 \\
\hline
\end{tabular}

\begin{tabular}{|l|ll|ll|ll|ll|ll|l}
\hline 309 & 0.54 & 237 & 0.41 & 169 & 0.29 & 62 & 0.11 & 14 & 0.02 & 3 & 0.01 \\
\hline
\end{tabular}

It is an undeniable fact that the analysis of the climatic data, the cover material used and the analysis of the relations with the flooring contributes to the landscape design. Developments in data mining allow data to be analyzed more easily and prediction models to be sharper. It is likely that more studies will be conducted on the subject in the coming years, including other cities and regions.

\section{References}

Carpenter PL, Walker TD, Lanphear FO. 1975. Plants in the Landscape. Purdue University.W.H. Freeman and Company. Page: 164-166. ISBN: 0-7167-0778-0. SanFrancisco. U.S.A.

Çetin M, Kaya L, Yılmaz B. 2010. Biyoiklimsel Konforun Peyzaj Planlama Sürecindeki Etkinliği: Kütahya Örneği. SDÜ Orman Fakültesi Dergisi 11 (1), 83 - 95.

Güngör S, Aslan M. 2003. Beyşehir İlçesi ve Yakın Çevresi Turizm ve Rekreasyon Kullanımına Yönelik Peyzaj Potansiyelinin Saptanması Üzerine Bir Araştırma. S.Ü. Ziraat Fakültesi Dergisi 17 (32):2003, 64 -73.
Kabalc1 E. 2014. Yapay Sinir Ağları. Ders Notları, https://ekblc.files.wordpress.com/ 2013/09/ysa.pdf

Marsh WM. 1991. Landscape Planning Environmental Applications, 2nd Edition. John Wiley\&Sons Inc. ISBN: 0471-52506-5. Page: 228-236. U.S.A.

Özdemir BB. 2015. Sürdürülebilir Çevre için Binaların Enerji Etkin Pasif Sistemler Olarak Tasarlanması, Yüksek lisans Tezi, İTÜ Mimarlık Fakültesi.Fen Bilimleri Enstitüsü.

Robinette GO, McClenon C. 1983. Landscape Planning for Energy Conservation. Van Nostrand Reinhold Co. ISBN: 0442-22339-0. Page: 63.

Sojoudihaassanlouei L. 2019. Sicak Kuru İklim Geleneksel Konutlarında İklime Duyarlı Tasarım. Hacettepe Üniversitesi Güzel Sanatlar Enstitüsü İç Mimarlık ve Çevre Tasarım Anabilim Dalı. Ankara.

Wang Y, Bakker F, Groot R, Wörtche H, Leemans R. 2015. Effects of Urban Trees on Local Outdoor Microclimate: Synthesizing Field Measurements by Numerical Modelling. Urban Ecosystems. 18. 10.1007/s11252-015-0447-7.

Yücer N. 2015. Yapıda Çevre ve Enerji, 1. Baskı, Nobel Yayınc1lk. 